\title{
Dynamics and cytochemistry of oogenesis in Astyanax fasciatus (Cuvier) (Teleostei, Characiformes, Characidae) from RioSapucaí, Minas Gerais State, Brazil
}

\author{
José Antonio Dias Garcia ${ }^{1}$ \\ Helena A.S. Chini ${ }^{2}$ \\ Edson Luis Maistro ${ }^{3}$ \\ Irani Quagio-Grassiotto 4
}

\begin{abstract}
Oogenesis involves a set of transformations which are undergone by female germ cells These cells change into oogonias and then into mature oocytes. Sexually mature female fish were collected monthly, during one year, from the Sapucaí River, a tributary of the Rio Grande, which is part of the Furnas Reservoir in the state of Minas Gerais. During the several stages of maturation, we observed small round oogonias with a large nucleus, a single nucleolus, and weakly stained cytoplasm with eosinophilic granules. The primary oocytes showed a large basophilic nucleus, with a developed peripheral nucleolus and a reduced cytoplasm. The previtellogenic oocytes presented voluminous cytoplasm and nucleus with several small peripheral nucleoli. The oocytes underwent vitellogenesis with the development of the zona radiata and the follicle cells. Their cytochemical reactions indicated that the two layers of the zona radiata of $A$. fasciatus contained proteins and polysaccharides. The initially squamous follicle cells, became cuboidal. In mature oocytes, the nucleus moved toward the periphery, next to the micropyle, and the yolk granules formed by proteins, fulfilled the cytoplasm. The clear unstained vesicles are likely to be the cortical alveoli in the perivitelline region.

KEY WORDS. Teleostei, Characidae, Astyanax fasciatus, oogenesis, cytochemical
\end{abstract}

The Characidae family, with about 400 species, comprises the majority of freshwater fishes in South America. Most of the Brazilian scaled fishes (lambaris, piracanjubas, piranhas, dourados, etc.), which are very appreciated in game fishing (BRISTSKI 1972), are found in this family.

Astyanax fasciatus (Cuvier, 1819), commonly known "as red-tail-lambari", is the most geographically spread lambari species in the neotropical region. Its caudal and dorsal fins are red, and its ventral and pectoral fins are hyaline, with golden reflexes. It is a small sized fish that feeds on algae, vegetation, larvae and adult insects (NOMURA 1984).

1) Faculdade de Medicina Veterinária, Departamento de Medicina Veterinária Preventiva, UNIFENAS. Caixa Postal 23, 37130-000 Alfenas, Minas Gerais, Brasil.

2) Instituto de Odontologia e Ciências da Saúde, UNIFENAS. Caixa Postal 23, 37130-000 Alfenas, Minas Gerais, Brasil.

3) Instituto de Farmácia e Nutrição, UNIFENAS. Caixa Postal 23, 37130-000 Alfenas, Minas Gerais, Brasil. E-mail: maistro.edson@unifenas.br

4) Departamento de Morfologia, Instituto de Biociências, Universidade Estadual Paulista. Campus Rubião Júnior, 18300-000 Botucatu, São Paulo, Brasil. 
Teleost fishes are predominantly dioicous and their reproduction is mainly cyclic, being influenced by seasonal and/or environmental conditions. During reproduction, their gonads undergo a series of morphological and physiological modifications (NAGAHAMA 1983).

In these fishes, female gametogenesis is a reference for determining the time of the year in which they are able to reproduce (WEST 1990).

In order to preserve aquatic ecosystems, it is necessary, among other things, to understand the reproductive processes of their ichthyofauna. One of the initial steps of this learning process is the study of gametogenesis.

Therefore, within this context, we have studied the dynamics and cytochemistry of oogenesis in Astyanax fasciatus from the Rio Sapucaí, Furnas Reservoir, Minas Gerais State, Brazil.

\section{MATERIAL AND METHODS}

Specimens of A. fasciatus were collected monthly, from August 1998 to July 1999, in the Rio Sapucaí, a tributary of the Rio Grande, Furnas Reservoir, Alfenas, Minas Gerais, Brazil ( $21^{\circ} 25^{\prime} 45^{\prime \prime}$; $45^{\circ} 56^{\prime} 50^{\prime \prime}$; average altitude $\left.849.2 \mathrm{~m}\right)$. A set of gill nets (10m long, $1.5 \mathrm{~m}$ high, $1.5 \mathrm{~cm}$ mesh size) were exposed for a $10-15 \mathrm{~h}$ period.

A total of 72 sexually mature females were removed alive from the nets and taken to the laboratory, where they had their cellomic cavity opened and gonads removed, sectioned and fixed overnight in KARNOVSKY (1964).

The fixed material was embedded in historesin, and cut on a microtome equipped with a glass knife. The $3-\mu \mathrm{m}$ sections were stained with: hematoxylin-eosin (HE), for general morphological analysis; Toluidin blue pH 4.0 (TB pH 4.0), for the detection of acid polysaccharides and phosphated cellular components (DNA and RNA); Toluidin blue $\mathrm{pH} 2.5$ (TB pH 2.5), for the detection of sulphated acid polysaccharides; Coello's Method (CM) (COELLO 1989), for the detection of neutral polysaccharides and proteins; and Fast Green pH 2.5 (FG), for the detection of total proteins. The slides thus prepared were observed, analyzed and photographed under an Olympus BX 50 photomicroscope.

\section{RESULTS AND DISCUSSION}

Astyanax fasciatus is a dioicous species, and like most teleosts (AzEVEDO et al. 1988a,b; SELMAN \& WALLACE 1989; BAZZOLI \& RIZZO 1990; RIZZO \& BAZZOLI 1993; BAZZOLI et al. 1996; TYLER \& SUMPTER 1996; VAZZOLER 1996), their gonads annually undergo great modifications until they become mature.

During ovarian maturity, the germ cells of A. fasciatus undergo different stages of development. The oogonias originate the primary oocytes that successively become previtellogenic oocytes, vitellogenic oocytes and mature oocytes. Atresic follicles may result from a failure in vitellogenesis or ovulation.

As described by CHAVES \& VAZZOLER (1984) in Semaprochilodus taeniurus (Velenciennes, 1821) and Semaprochilodus insignis (Jardim \& Schombrerk, 1841); RIzzO \& BAZzOLI (1993) in Prochilodus affinis Reinhardt, 1874 and VAZzOLER (1996) in other teleosts, the oogonias are found grouped in nests inserted in ovarian

Revta bras. Zool. 18 (4): 1057 - 1064, 2001 
lamellae. In our study, the oogonias of A. fasciatus were observed to be small round cells, with a weakly stained cytoplasm containing eosinophilic granulations, and a big spherical nucleus with a single central nucleolus (Fig. 1). These morphological characteristics agree with those observed by RIZZO \& BAZZOLI (1993) in this type of cell.

In the present study, the primary oocytes of A. fasciatus were found in nests, showed a reduced cytoplasm and a big basophilic nucleus (Fig. 1). They were enveloped by prefollicle cells, left the nests and started to develop (Fig. 2). The growing oocytes observed correspond to those identified as young or previtellogenic oocytes by BAZzoli \& Rizzo (1990) and Rizzo \& BAZzOLI (1993), and as perinucleolar or reserve oocytes by VAZZOLER (1996). They showed 1 or 2 spherical and intensely basophilic nucleoli, which became larger in number and volume and migrated to the periphery of the nucleus. These were always present in the gonads, being initially round and becaming triangular, rectangular and oval afterwards, due to the pressure applied against each other (Fig. 2). In these oocytes it was possible to notice the vitelline nucleus (Balbiani's vitelline body), mentioned by Hubbard (1894 - apud SELMAN \& WALLACE 1989) as an outstanding characteristic of the previtellogenic stage. Balbiani's vitelline body or vitelline nucleus (VN) seen in the oocytes of A. fasciatus, similarly to that described by BAzzoli \& GodinHo (1997) in Pseudoplatystoma coruscans and Lophiosilurus alexandri, showed circular outline and was located next to the nucleus (Fig. 2). It differed from the rest of the cytoplasm by displaying a coarser granulation (Fig. 2). It also looked similar to those described in previtellogenic oocytes of Oryzias latipes by Yamamoto \& YoshiOKA (1964), Syngnathus fuscus Storer, 1839 and Fundulus heteroclitus Linnaeus, 1776 by ANDERSON (1968) and several other teleosts revised by TYLER \& SUMPTER (1996). In the previtellogenic oocytes of A. fasciatus, the volume of the cytoplasm was increased, remarkably diminishing the nucleus/cytoplasm relationship (Fig. 3). The nucleus showed irregular outline and the nucleoli originated many other small and peripherical nucleoli (Fig. 3). The cytoplasm showed coarse granulations (Fig. 3), which probably originated from the vitelline nucleus (BAZZOLI \& GODINHO 1995). These characteristics agree with those observed by Wallace \& Selman (1981), Nagahama (1983), SELman \& Wallace (1989), BAZZOLI \& RIZZO (1990), RIZzo \& BAZzOLI (1993) and VAZZOLER (1996) in other teleosts. The previtellogenic oocytes also showed a thin layer of squamous follicle cells whose nuclei were flat (Fig. 3). At this stage, between the oocyte and the follicle envelope, appeared the zona radiata, a thin acellular layer homogeneously stained with eosin (Fig. 3). This envelope kept on developing throughout the oocyte growth (TYLER $\&$ SUMPTER 1996).

The vitellogenesis started with the onset of clear vesicles in the peripheral cytoplasm of A. fasciatus oocytes (Fig. 4). These vesicles were the cortical alveoli and their precursors. Next, yolk deposition occurred in intensely eosinophilic globules that progressively increased in number and size (Figs 4-5).

This stage of oocyte development, with the presence of oocytes with cortical alveoli (Wallace \& Selman 1981; Nagahama 1983; De Vlaming 1983; SelMAN \& WALLACE 1989; BAZZOLI \& RIZZO 1990; RIzZO \& BAZZOLI 1993; SUMPTER et al. 1994; TYLER \& SUMPTER 1996), definitely indicate ovulation. 

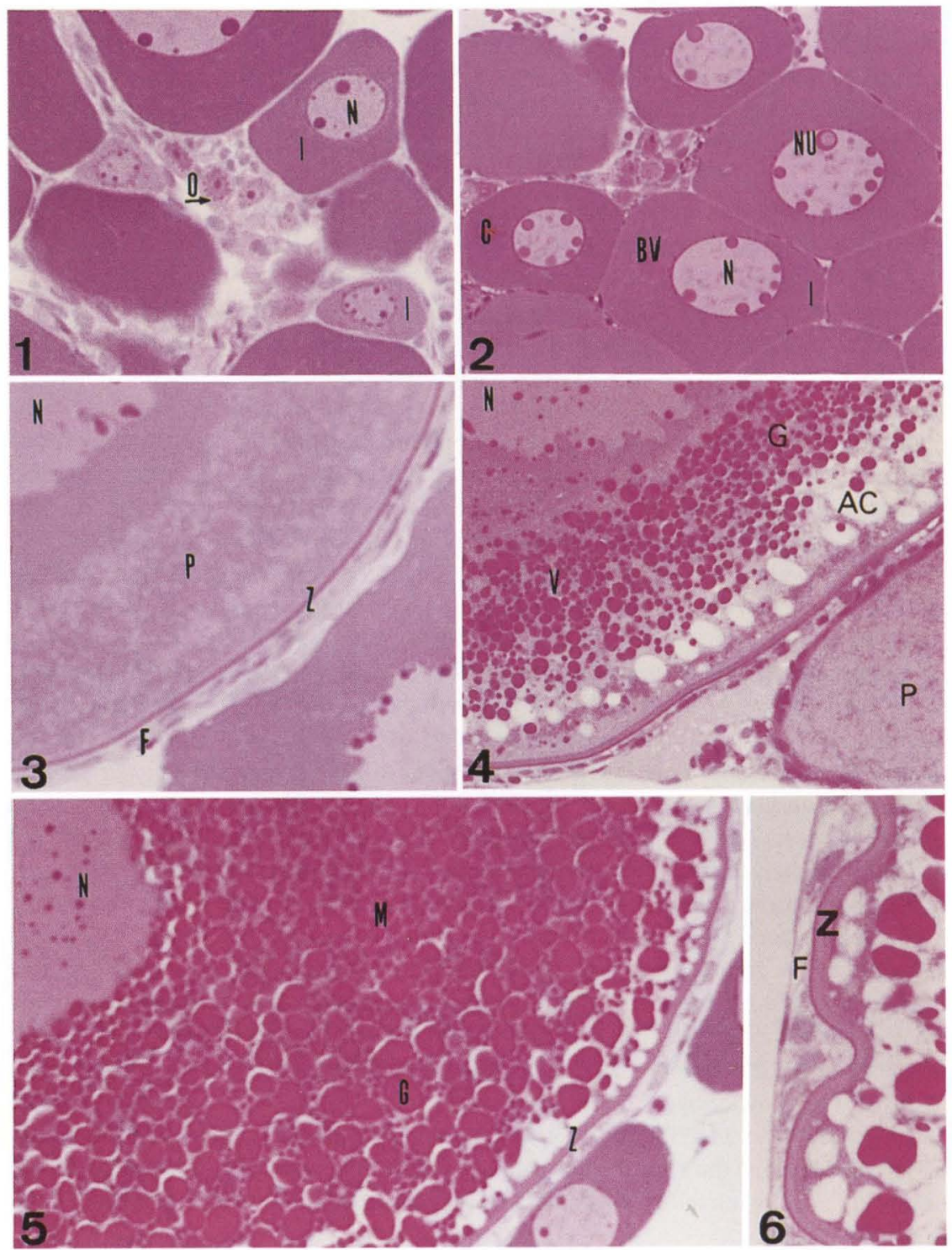

Figs 1-6. (1) Oogonia (O): primary oocyte (I), nucleus (N), nucleoli (NU), HE; (2) primary oocyte (I): cytoplasm (C), nucleus (N), nucleoli (NU), Balbiani's vitelline body (BV), HE; (3) previtellogenic oocyte $(P)$ : nucleus $(N)$, zona radiata $(Z)$, follicle cells $(F), H E ;(4)$ vitellogenic oocyte $(V)$ : previtellogenic oocyte $(P)$, cortical alveoli $(A C)$, yolk globules $(G)$, nucleus $(N), H E ;(5)$ mature oocyte $(M)$ : zona radiata $(Z)$, yolk globules $(G)$, nucleus $(N), H E ;(6)$ zona radiata $(Z)$ : follicle cells (F), HE. 


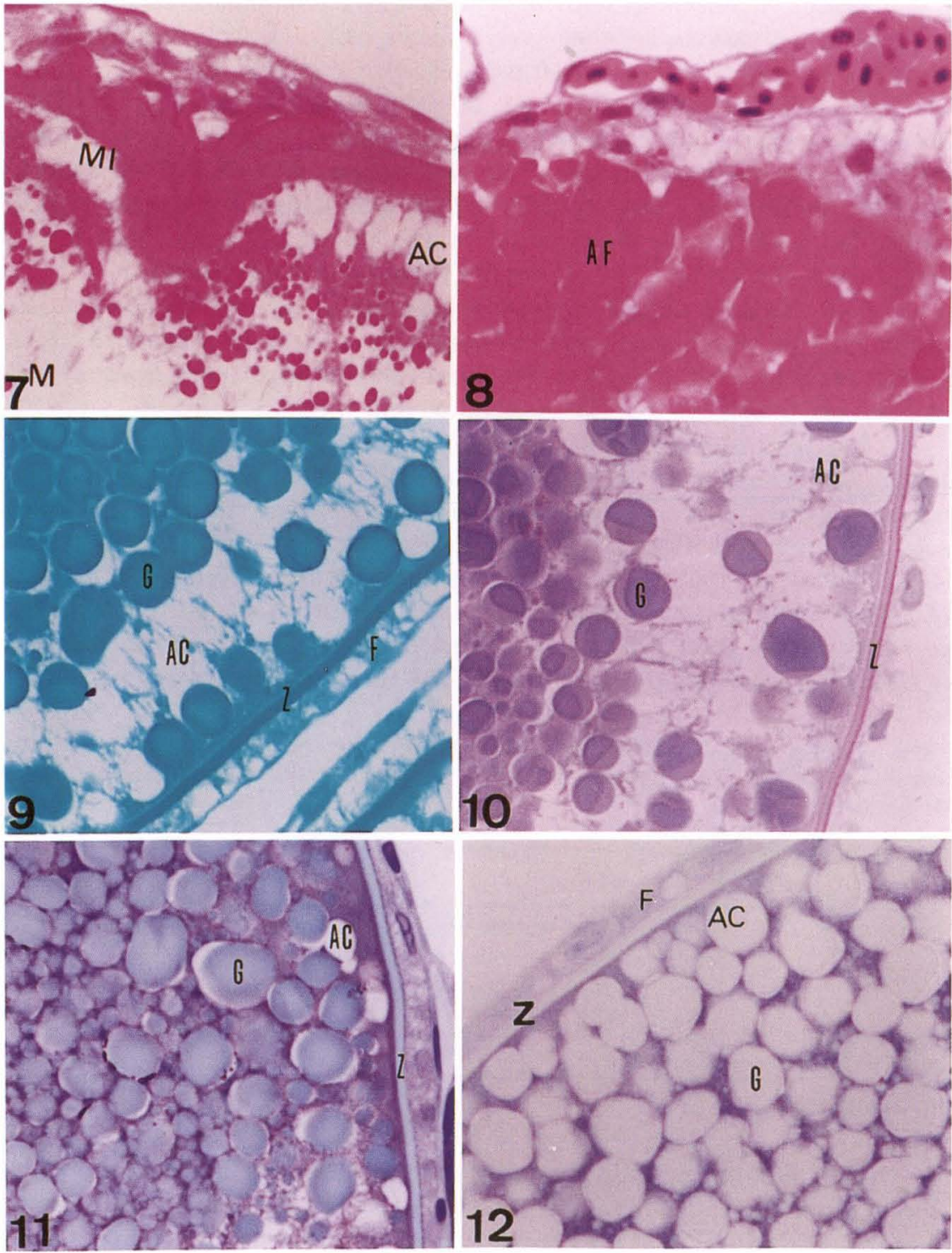

Figs 7-12. (7) Mature oocyte (M): micropyle (MI), cortical alveoli (AC), HE; (8) atresic follicle $(A F)$ : HE; (9) follicle cells $(F)$ : zona radiata $(Z)$, cortical alveoli $(A C)$, yolk globules $(G), F G ;(10)$ zona radiata $(\mathrm{Z})$ : cortical alveoli $(\mathrm{AC})$, yolk globules $(\mathrm{G}), \mathrm{MC}$; (11) zona radiata $(\mathrm{Z})$ : cortical alveoli $(A C)$, yolk globules $(G), T B ~ p H ~ 4.0 ;(12)$ zona radiata $(Z)$ : cortical alveoli $(A C)$, yolk globules (G), TB pH 2.5. 
During vitellogenesis in Astyanax fasciatus, the zona radiata becomes thicker and presented occasional undulations (Fig. 6). Similarly to R. xenodon (BAzzOLI et al. 1996), two layers inner and outer were also evidenced (Fig. 6).

In mature oocytes of A. fasciatus, the cytoplasm changed completely, due to the rapid increase of yolk globules, which were spherical in shape and did not fuse until the end of vitellogenesis (Fig. 5). In these oocytes, the nucleus contracted and migrated towards the micropyle (Fig. 7). The zona radiata was homogeneously stained by eosin and the follicle cells became cuboidal (Fig. 6). This stage is described by VAZZOLER (1996) as oocytes in complete vitellogenesis.

In A. fasciatus, atresic follicles were occasional, resulting from non-ovulated mature oocytes, whose characteristics were similar to those described by Rizzo \& BAZZOLI (1995) and VAZZOLER (1996): loss of cellular turgescence, fusion of yolk globules and increase in theca vascularization (Fig. 8).

The cytochemical analysis (Tab. I) of oocytes of A. fasciatus showed that the zona radiata is positive for FG, and, when stained by the Coello's method, responds in magenta, more intensely in the outer than in the inner layer. Therefore, it contains neutral glycoproteins (Figs. 9-10), which seems to be widely found among teleosts (BAZZOLI \& RIZZO 1990). However, other cytochemical studies revealed the presence of carboxylated acid glycoconjugates in the outer layer of this envelope in Moenkhausia costae (Steindachner, 1907), and glycoproteins rich in sialic acid in the outer layer of Hemigramus marginatus Ellis, 1911 (BAzzoLl et al. 1996).

Table I. Oocyte content (mature oocyte) and respective cytochemical reactions in Astyanax fasciatus, collected in Rio Sapucaí, tributary of the Rio Grande, Furnas Reservoir, Minas Gerais, Brazil.

\begin{tabular}{|c|c|c|c|c|}
\hline \multirow[t]{2}{*}{ Cytochemical reactions } & \multirow[t]{2}{*}{ Cortical alveoli } & \multirow[t]{2}{*}{ Yolk globules } & \multicolumn{2}{|c|}{ Zona radiata } \\
\hline & & & Outer layer & Inner layer \\
\hline Coello's Method & - & Proteins (Purplish blue) & $\begin{array}{l}\text { Neutral Glycoproteins } \\
\text { (Magenta) }\end{array}$ & $\begin{array}{l}\text { Neutral glycoproteins } \\
\text { (Rosy) }\end{array}$ \\
\hline Fast Green ( $\mathrm{pH} 2.5$ ) & & $\begin{array}{l}\text { Proteins } \\
\text { (Green at the edge and light } \\
\text { green inside the globule) }\end{array}$ & $\begin{array}{l}\text { Neutral glycoproteins } \\
\text { (Green) }\end{array}$ & $\begin{array}{l}\text { Neutral glycoproteins } \\
\text { (Light green) }\end{array}$ \\
\hline Toluidin Blue ( $\mathrm{pH} 4.0$ ) & - & - & - & - \\
\hline Toluidin Blue ( $\mathrm{pH} 2.5$ ) & - & - & - & - \\
\hline
\end{tabular}

(-) No response.

In A. fasciatus, the yolk globules of oocytes in vitellogenesis showed proteins (Figs 9-12). In other neotropical freshwater teleosts studied by BAzzoLI \& RIzzo (1990) and BAZZOLI et al. (1996), besides proteins, the yolk globules showed neutral glycoproteins in some species and neutral lipids in others.

In the perivitelline region (periphery of the cytoplasm) of mature oocytes of A. fasciatus, clear vesicles that did not respond to the staining used were found, which are likely to be the cortical alveoli (Figs 9-12). The same was described by NEVES et al. (1995) in oocytes of Oligosarcus argenteus Günther, 1864. According to this author, the content of cortical vesicles changes during oocyte maturation. Other authors (NAGAHAMA 1983; SElman \& WALlaCE 1989; WeST 1990; TYLER 
\& SUMPTER 1996), also reported that cortical alveoli may respond to specific stains used for proteins and carbohydrates.

BAZZOLI \& GODINHO (1994), studying several neotropical teleosts, demonstrated that cortical alveoli contain polysaccharides which form glycoconjugates or glycoproteins. According to KITAYAMA et al. (1994 apud TYLER \& SUMPTER 1996), these polysaccharides are important to avoid polyspermia during fertilization.

The chemical composition of the different oocytes structures and the oogenesis dinamics in Astyanax fasciatus is similar to the ones observed in other freshwater teleosts with external fertilization, according to the idea that the female gametogenesis in Teleostean fishes is linked to the reproductive tactics of the species.

ACKNOWLEDGEMENTS. The authors are grateful to Mr. Antônio Vicente Salvador and Mr. Ricardo André dos Santos for their technical help, and Dr. Francisco Langeani Filho for identifying the specimens. Funds supporting this study were provided by FAPEMIG, Hidroelétrica de Furnas and Universidade de Alfenas.

\section{REFERENCES}

ANDERSON, E. 1968. Cortical alveoli formation and vitellogenesis during oocyte differentiation in the pipefish, Syngnathus fuscus and the killifish. Fundulus heteroclitus. Jour. Morphol. 125: 23-60.

Azevedo, C.O.; M.C. Barbieri \& G. Barbieri. 1988a. Ciclo reprodutivo de Parodon tortuosus (Eigenmann \& Norris, 1900) do Rio Passa Cinco, Ipeúna, SP. I. Estádio de maturação dos testículos. Época de reprodução. Rev. Brasil. Biol. 48: 565-569.

-1988b. Ciclo reprodutivo de Parodon tortuosus (Eigenmann and Norris, 1900) do Rio Passa Cinco, Ipeúna, SP. I. Estádio de maturação dos testículos. Época de reprodução. Rev. Brasil. Biol. 48: $571-575$.

Bazzoli, N. \& E. Rizzo. 1990. A comparative cytological and cytochemical study of the oogenesis in tem Brazilian teleost fish species. Eur. Arch. Biol. 101 (4): 399-410.

Bazzoli, N. \& H.P. Godinho. 1994. Cortical alveoli in oocytes of freshwater neotropical teleost fish. Bol. Zool. 61 (4): 301-308.

1995. Comparative morphogy of the yolk nucleus (Balbiani body) in freshwater neotropical teleost fish. Rev. Brasil Biol. 55: 207-214.

— 1997. Ovócitos vitogênicos do surubim Pseudoplatystoma coruscans e do pacamã Lophiosilurus alexandri. Coleção Meio Ambiente. Belo Horizonte, 19: 81-90.

Bazzoli, N.; E. Rizzo; J.E. Santos \& Y. Sato. 1996. Dinâmica da ovogênese em peixes forrageiros da represa de Três Marias, Minas Gerais: estudo histológico e histoquímico. BIOS, Belo Horizonte, 4: (4): $5-10$.

BRISTSKI, H.A. 1972. Peixes de água doce do Estado de São Paulo: Sistemática, p. 79-108. S. M. Branco (Ed.) In: Poluição e Piscicultura. São Paulo, Faculdade de Saúde Pública, USP, Instituto de Pesca CPRN/SA, 216p.

Chaves, P.T.C. \& A.E.A.M. VAzzoler. 1984. Aspectos biológicos de peixes amazônicos. II. Anatomia microscópica de ovários, escala de maturidade e tipo de desova das espécies do gênero Semaprochilodus. Rev. Brasil. Biol. 44: 347-359.

Coello, S.A. 1989. New staining schedule for formalin-fixed, glicol methacrylate- embedded fish ovaries. Jour. Fish Biol. 34: 329-330.

DE VLAMING, V. 1983. Oocyte development patterns and hormonal involvements among teleost, p. 176-199. In: J.C. Rankin; T.J. Pitcher \& R.T. Duggan (Eds). Control processes in fish physiology. Croom Helm, London \& Canberra, 287p. 
KARNOVSKY, J.M. 1964. A formaldehyde-glutaraldehyde fixative of high osmolarity for use in Eletron Microscopy. Jour. Cell Biol. 27: 137.

Nagahama, Y. 1983. The functional morphology of teleost gonads. p. 223-276. In: W.S. Hoar; D.J.

Randall \& E.M. Donaldson (Eds). Fish Physiology. 9. Reproduction, part A. New York, Academic Press, 338p.

Neves, C.A.; D.R. Andrade; S.L.P MatTa; M.V. Vidal \& A.A. Santos. 1995. Cytochemical analysis of polysaccharides from the cortical alveoli of the oocytes of the lambari-bocarra (Oligosarcurs argenteus Günther, 1864) (Pisces, Characidae). Rev. Brasil. Biol. 55: 693-696.

Nomura, H. 1984. Dicionário dos peixes do Brasil. Brasília, Editerra, 482p.

Rizzo, E. \& N. BAzzoli. 1993. Oogenesis, oocyte surface and micropylar apparatus of Prochilodus affinus Reinhardt, 1874 (Pisces, Characiformes). Eur. Arch. Biol. 104: 1-6.

. 1995. Follicular atresia in Prochilodus affinis Reinhardt, 1874 (Pisces, Characiformes). Rev. Brasil. Biol. 55: (4); 697-703.

Selman, K. \& R.A. Wallace. 1989.Cellular aspects of oocyte growth in teleosts. Zool. Scien., CIDADE?, 6: 211-231.

SumPteR, J.P.; A.P. SCOTT; S.M. BAyneS \& P.R. WitThames. 1994. Early stages of the reproductive cyle in virgin female rainbow trout (Salmo gairdneri Richardson). Aquaculture 43: 235-242.

TYleR, C.R. \& J.P. Sumpter. 1996. Oocyte growth and development in teleosts. Rev. Fish Biol. Fresheries 6: 287-318.

VAZzoLER, A.E.A.M. 1996. Biologia da reprodução de peixes teleósteos. Teoria e Prática. Maringá, EDUEM, 169p.

Wallace, R.A. \& K. Selman. 1981. Cellular and dynamic aspect of oocyte growth in teleosts. Scien Zool. 21: 325-343.

WEST, G. 1990. Methods of assessing ovarian development in fish: a review. Aust. Jour. Mar. Freshw. Res. 41 (2): 199-222.

Yамамото, K. \& H. YosнioкA. 1964. Rhythm of development in the oocyte of medaka, Oryzias latipes. Bull. Fac. Fish. Hokkaido Univ. 15 (1): 50-19.

Recebido em 31.VIII.2000; aceito em 15.X.2001. 